
\title{
TJBF THE ROLE OF BANK LOANS AND
DEPOSITS IN THE MONETARY TRANSMISSION MECHANISM IN MALAYSIA
}

\author{
Salina Kassim and M. Shabri A. Majid \\ International Islamic University of Malaysia
}

\begin{abstract}
This study attempts to determine the importance of the banking sector in the monetary transmission process in a developing economy. The study analyzes the Malaysian data focusing on three sample periods: the entire sample period (1989:01-2006:12); the pre-crisis period (1989:01-1996:12); and the post-crisis period (1999:01-2006:12). To achieve this objective, the study relies on two tests: first, the auto-regressive distributed lag (ARDL) model for the long-run relationship among the variables and second, the impulse response functions and variance decomposition analysis for the short-run relationship among the variables. The finding shows that both bank deposits and loans play crucial roles in the monetary transmission process in the economy, suggesting evidence for the money endogeneity theory of post-Keynesian economists. In particular, bank deposits and loans are shown to provide an important link from monetary policy to output. This underscores the importance of ensuring the soundness of banking system as a pre-requisite to economic stability in the absence of such market based tools as market-based actions on exchange rate or interest rates as monetary stabilisation tools.
\end{abstract}

Keywords: Monetary transmission, Bank loans, Bank deposits, Auto-regressive distributed lag model; Impulse response functions, Variance decompositions

JEL Classifications: E42, E51, G21

\section{Introduction}

While it is widely accepted that monetary policy affects macroeconomic outcomes in an economy, a central point of a continuing debate among the policy-making circles is on the transmission mechanism of monetary policy to the real economy. The debate arises from the importance of identifying the key link(s) since such link(s) will determine the effective instrument and reliable intermediate targets for monetary policy implementation. In view of this, 


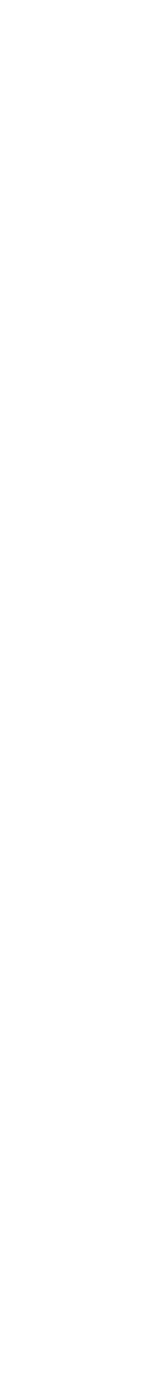

identifying the relevant channels through which the impact of monetary policy is transmitted to the real economy has been one of the most challenging and crucial tasks in the conduct of monetary policy. A clear understanding of the monetary transmission channel can help in ensuring an effective and successful implementation of monetary policy. Besides, the post-Keynesian economists have emphasized the role of banking credits as the key transmission mechanism, although this paper is not directly testing that hypothesis. This aspect has yet been seriously studied, and the only study that exists of a developing country is that of Turkey.

Monetary policy affects the real economy via several channels, but the main two that are often mentioned in the literature are the "money channel" and "credit channel". The money channel, which emphasises the role of central bank's money in the monetary transmission process, has secured a strong footing in the economic literature (see, for example, Brunner and Meltzer, 1972, 1988, 1990; McCallum, 1990, 1999, 2001, 2004; McCallum and Nelson, 2005; Feldstein and Stock, 1993; Hess and Porter, 1993; Dotsey and Otrok, 1994; Meltzer, 1969, 1970, 2001; Christiano and Rostagno, 2001; and Nelson, 2003a, 2003b). According to this view, an expansionary monetary policy causes bank deposit and money supply to expand, which results in real interest rate to decline, thus it is also known as the interest rate channel.

Studies that are supportive of the existence and importance of the bank lending channel in general find that, bank loan behave in a predictable manner when a policy shock is exerted on the economy. When a central bank conducts open market operations to reduce liquidity in the system, bank's deposit and liquidity are reduced, thereby restricting the ability of banks to supply new loans. Credit is less available in the economy, resulting in firms to cut down on investment and production, thus lower aggregate output in the economy. On the other hand, studies that do not support the importance of the bank lending channel generally find that banks offset the decline in liquidity following a tight monetary policy by adjusting their balance sheet items. Such ability to do so renders monetary policy ineffective in influencing supply of bank loan remaining relatively unchanged even after the implementation of the tight policy stance. For example, Suzuki (2001) employs the VAR analysis to examine the bank lending channel using the Australian data and report that bank loans contracted following a tight monetary policy, the contraction. Studies by Morris and Sellon (1995) which used US data for 1974-1990 also show that bank loan is not an important channel for monetary policy since bank loan supply does not decline in response to tight monetary policy.

Earlier studies such as Scholnick (1996) and Tan (1997) on Malaysian situation adopted the credit-rationing model and estimated the disequilibrium model of lending rate. Both studies support the presence of credit rationing as the lending rate adjusted very slowly and did not clear the loan market. More recent studies such as Ibrahim (2005), Azali (2003), Tang (2000, 2002) and Vaithilingam et al. (2003) employed more recent investigation techniques such as the VAR that enable more detailed and conclusive findings. In general, 
these studies are supportive of the important role played by bank loan in the transmission of monetary policy.

The need to understand the interaction between bank loan and bank deposit with monetary policy indicator is critical, hence this study is motivated to address this issue. Bank lending accounted for more than 100 percent of the country's total gross domestic product (GDP) and is expected to remain high due to the moderate economic performance. Indeed, the important role played by bank lending in achieving the overall economic objective is clearly acknowledged by Bank Negara Malaysia. "As the nation's monetary authority, the Central Bank is responsible to the Government for promoting monetary stability and a sound financial structure, and for influencing the credit situation to help achieve the nation's overall economic objectives." (1994, p. 91). An aspect of novelty of this study is that not only that it uses the latest empirical methodology, it also considers two sub-sample periods following the crisis in 1997/1998.

The rest of this paper is organized as follows: the next section provides some background information on the monetary transmission process. Section 3 discusses the data and empirical framework. Section 4 presents the empirical findings and the discussions of the results. Lastly, Section 5 concludes this paper.

\section{An Overview of Related Literature}

Empirical studies analyzing the importance of the banking sector in the monetary transmission process focus on the relationship and impact of disturbances in the banking sector on the aggregate economic activity: see, for example Friedman,1984; Bernanke and Blinder, 1988 and 1992; Bernanke and Gertler, 1995; Bernanke and Mihov, 1998; Dale and Haldane, 1998; Domac and Ferri, 1998; Garretsen and Swank, 1998; Guender, 1998; Gertler and Gilchrist, 1993; Walsh and Wilcox, 1995 and Suzuki, 2001. In general, these studies measure the responses of selected macroeconomic variables such as output, unemployment rate and inflation and the major bank balance sheet variables, which are deposit (representing bank liability) and loan (representing bank asset) to changes in the monetary policy indicator such as interest rates.

However, it is often shown that the macroeconomic responses to policyinduced interest rate changes are larger than that implied by the money view. This gives rise to the lending channel, which suggests that bank loans may provide an additional channel for the monetary authority to affect the real economy. An influential study by Bernanke (1983) finds that the output decline in the US during the 1930-1933 Great Depression cannot be fully explained by monetary disturbances as described by the money view. Using the federal funds rate as an indicator for monetary policy, that study analyzed the responses of selected macroeconomic variables such as unemployment rate and inflation, and the bank balance sheet items to changes in the fed funds rate. It was found that in the short run, banks offset the decline in liquidity following a contractionary monetary policy by selling-off their securities holdings, thereby leaving the supply of 
loan in the economy virtually unchanged. However, in the longer term, the tight monetary policy causes banks to terminate the existing loans and stop making new loans. The brunt of the tight monetary policy is especially felt by borrowers who are dependent on bank lending. Consequently, the tighter monetary policy results in a decline in the aggregate economic output. Until now, the reduction in loan supply has often been quoted as one of the reasons for the depth and persistence of the Great Depression. As lessons learned from that crisis, the central banks the world over are loosening monetary policy since August 2007 in response to the sub-prime loan crisis of 2007/08.

In Malaysia, the banking system forms an integral part of a larger financial system which is made up of the financial institutions and the financial markets. The financial institutions can be grouped into the banking system and the nonbank financial intermediaries. The banking system is made up of commercial banks, finance companies and merchant banks, while the non-bank financial intermediaries comprised the provident and pension funds, insurance companies, development financial institutions, savings institutions and other financial intermediaries (such as cooperative societies, leasing and factoring companies, venture capital companies and housing credit institutions). The operations of Malaysia's banking system fall under the purview of the central bank, the Bank Negara Malaysia (BNM).

The financial system experienced a rapid growth in tandem with the robust economic performance during 1976-1996. By the end of 2006, the total assets of the financial system was about equal to the GDP of the country and it was RM2,091.2 or US\$ 635 billion compared to RM329.3 billion in 1990 and RM74.2 billion in 1980. The rapid growth financial sector reflects the process of financial deepening due to increased demands for financial products and services in line with the structural transformation of the economy. More importantly, the banking system remained a major contributor to the total assets of the country's financial system.

Of the total assets of the financial system at end-2006, 68 percent were contributed by the banking system while 32 by the non-bank financial intermediaries. In terms of growth, the total assets of the banking system grew by approximately 11.3 percent in the period of 1990-2006, comparable to that of the financial system at 11.5 percent. Apart from its significant contribution to the growth of the country's financial system, the banking system has also been instrumental in financing the country's economic growth. This is well-reflected by the high ratio of total loan extended by the banking institutions to total gross domestic product (GDP) at more than 100 percent as at end-2006.

One important lesson learned from the 1997/98 Asian financial crisis was that fragility of the banking sector could lead to a loss of confidence which would affect the real economy negatively. In view of this, BNM banking policies in the post-crisis period are directed towards strengthening and increasing the resilience of the banking system as well as to preserve the integrity and stability of financial sector. In this regard, one of the major initiatives taken was to consolidate the banking institutions in order to create a core of strong domestic banking institutions with large capital base. Prior to the consolidation program, 
as at end-1997, the banking system comprised 35 commercial banks, 39 finance companies and 12 merchant banks. As a result of the consolidation program, as at end-2006, the number of commercial banks has been reduced to 22 operating within ten holding companies, with the operations of the finance companies fully being absorbed by the commercial banks and the merchant banks being re-categorized into the 14 investment banks comprising the merchant banks and discount houses. This led to a strong capital base of risk-weighted capital ratio at 13.5 percent as at end-2006. The non-performing loan ratio declined from above 13.9 percent in 1998 to 3.7 percent.

\section{Data and Methodology}

\section{A. Data}

The overnight rate, henceforth denoted as ONR is used as the monetary policy indicator, while the objective variables comprised of the bank balance sheet items, namely, bank loans (BL) and bank deposits (BD) and other variables which are consumer price index (CPI) and industrial production index (IPI). The CPI and the IPI are used as the proxies for inflation and level of economic activity, respectively. Given that the economy is a highly open one, the conduct of monetary policy may be influenced by foreign shocks, thus we also include real effective exchange rate (RER) as a control variable. All series are real (adjusted by price index with the year 2000 as base year) and variables are expressed in logarithm, except for the interest rate.

The study uses monthly data from January 1989 to December 2006. During this period, the economy experienced a financial crisis. To avoid the disturbance from affecting the results of the analysis, tests are done over separate subperiods and also over the whole period. The pre-crisis period covers the period from January 1989 to December 1996. In this period, the data set excludes the period from 1997 to 1998, which were the heights of the East Asian financial crisis. The post-crisis period runs from January 1999 to December 2006. All data are sourced from BNM's Monthly Statistical Bulletin, except for the RER which is gathered from International Financial Statistics published by International Monetary Fund.

\section{B. Empirical Framework}

ARDL Bound Testing Approach

The long-run dynamic relationships between monetary policy variables and bank balance sheet items are estimated by using the newly proposed ARDL bound testing approach: Pesaran et al. (1996). The ARDL has numerous advantages. First, unlike the most widely used method for testing cointegration, the ARDL approach can be applied regardless of the stationary properties of the variables in the samples and it allows for inferences on long-run estimates, which is not possible under the alternative cointegration procedures. This procedure can be applied irrespective of whether the series are $I(0), I(1)$, or fractionally integrated (Pesaran and Pesaran 1997; and Bahmani-Oskooee and Wing Ng, 2002), thus 
avoiding problems resulting from non-stationary time series data (Laurenceson and Chai, 2003). Second, the ARDL model takes sufficient numbers of lags to capture the data generating process in a general-to-specific modelling framework (Laurenceson and Chai, 2003). It estimates $(p+1)^{\mathrm{k}}$ number of regressions in order to obtain optimal lag-length for each variable, where $p$ is the maximum lag to be used, $k$ is the number of variables in the equation. Finally, the ARDL approach provides robust results for a smaller sample size of cointegration analysis. Since the sample size of our study is small, particularly for pre- and post-crisis subperiods, this provides a motivation for the study to adopt this model.

Ideally, for the purpose of this study, we needed to incorporate all the variables in the model, but a VAR model can be poorly estimated in a finite sample, as the addition of a variable will quickly exhaust the degree of freedom. Following Gertler and Gilchrist (1993, 1994), we estimated a series of separate VAR models including INF, IPI, and RER, policy variable (ONR), and the bank balance sheet items. Thus, our models contain only five variables. The ARDL models for the bank balance sheet items used in this study can be written as follows:

$$
\begin{aligned}
& B D_{t}=\delta_{0}+\phi_{1} O N R_{\mathrm{t}}+\varphi_{2} I P I_{t}+\gamma_{3} R E R_{t}+\mu_{4} I N F_{t}+\epsilon_{t} \\
& B L_{t}=\delta_{0}+\phi_{1} O N R_{\mathrm{t}}+\varphi_{2} I P I_{t}+\gamma_{3} R E R_{t}+\mu_{4} I N F_{t}+\varepsilon_{t}
\end{aligned}
$$

The error correction version of ARDL framework pertaining to the variables in the Equations (1.1) and (1.2) can be reproduced as follows:

$$
\begin{aligned}
& \Delta \mathrm{BD}_{\mathrm{t}}=\delta_{0}+\sum_{\mathrm{i}=1}^{\mathrm{p}} \theta_{\mathrm{i}} \Delta \mathrm{BD}_{\mathrm{t}-\mathrm{i}}+\sum_{i=0}^{\mathrm{p}} \phi_{\mathrm{i}} \Delta \mathrm{ONR}_{\mathrm{t}-\mathrm{i}}+\sum_{i=0}^{\mathrm{p}} \varphi_{\mathrm{i}} \mathrm{IPI}_{\mathrm{ti}}+\sum_{\mathrm{i}=0}^{\mathrm{p}} \gamma_{\mathrm{i}} \Delta \mathrm{RER}_{\mathrm{t}-\mathrm{i}}+\sum_{\mathrm{i}=0}^{\mathrm{p}} \mu_{\mathrm{i}} \Delta \mathrm{NNF}_{\mathrm{t}-\mathrm{i}}+ \\
& +\lambda_{1} \mathrm{BD}_{\mathrm{t}-1}+\lambda_{2} \mathrm{ONR}_{\mathrm{t}-1}+\lambda_{3} \mathrm{IPI}_{\mathrm{t}-1}+\lambda_{4} \mathrm{RER}_{\mathrm{t}-1}+\lambda_{5} \mathrm{INF}_{\mathrm{t}-1}+\notin_{1 \mathrm{t}}
\end{aligned}
$$

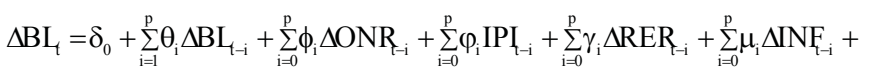

$$
\begin{aligned}
& +\lambda_{1} \mathrm{BL}_{\mathrm{t}-1}+\lambda_{2} \mathrm{ONR}_{\mathrm{t}-1}+\lambda_{3} \mathrm{IPI}_{\mathrm{t}-1}+\lambda_{4} \mathrm{RER}_{\mathrm{t}-1}+\lambda_{5} \mathrm{INF}_{\mathrm{t}-1}+\varepsilon_{1 \mathrm{t}}
\end{aligned}
$$

In the above equations, the terms with the summation signs represent the error correction dynamics, while the second part (term with $\lambda s$ ) correspond to the long-run relationship. The null of no cointegration in the long-run relationship is defined by $H_{0}: \lambda_{1} \neq \lambda_{2} \neq \lambda_{3} \neq \lambda_{4} \neq \lambda_{5=} 0$ which is tested against the alternative of $H_{0}: \lambda_{1} \neq \lambda_{2} \neq \lambda_{3} \neq \lambda_{4} \neq \lambda_{5} \neq 0$, by the means of familiar F-test. However, the asymptotic distribution of this F-statistic is non-standard irrespective of whether the variables are $I(0)$ or $I(1)$. Pesaran et al. (1996) have tabulated two sets of appropriate critical values. One set assumes all variables are $I(1)$ and another assumes that they are all $I(0)$. This provides a bound covering all possible classifications of the variables into $I(1)$ and $I(0)$ or even fractionally integrated. If the F-statistic lies above the upper-bound level, the null hypothesis is rejected, which indicates the existence of cointegration. However, if the F-statistic falls below the bound level, the null cannot be rejected, showing that no cointegration 
exists. If, however, it falls within the band, the result is inconclusive. Finally, in order to determine the optimal lag-length incorporated into the model and select the ARDL model to be estimated, the study employs the Akaike Information Criteria (AIC).

Impulse Response Functions and Variance Decompositions

We estimate VAR models and generate impulse-response functions to study the impacts of interest rate shocks on the systems as indicated in equations 1.1 and 1.2. An impulse response function (IRF) measures the time profile of the effect of shocks at a given point in time on the (expected) future values of variables in a dynamical system (Pesaran and Shin, 1998). The approach is wellsuited because not only that it allows for the relative strength of various shocks to be quantified in terms of their contributions to variations in a particular variable of interest, but it also enables the pattern and direction of the transmission of shocks to be traced.

Meanwhile, the Variance Decomposition Analysis (VDA) shows the fraction of forecast error variance of a variable attributed to shocks in other variable particularly to inference of relative strength of innovations in the variable of interest. It is a method of providing a literal breakdown of the change in the value of a variable in a given period arising from changes in the same variable and in other variables during previous periods. Variance decomposition analysis provides an indication of the dynamic properties of the system. VDC, which is termed an out-of-sample causality tests, by partitioning the variance of forecast error of a certain variable into proportions attributable to innovations (or shocks) in each variable in the system including its own, can provide an indication of these relatives. According to Sims (1992), a variable optimally forecast from its own lagged values will have all its forecast error variance accounted for by its own disturbances. It is generally observed that in applied research, it is typical for a variance to explain almost all its forecast error variance at short horizons and smaller proportions at longer horizons.

\section{Empirical Results and Analysis}

\section{A. Results based on the ARDL Model}

In estimating the long-run relationships between the monetary policy variable and the objective variables (consisting of the bank balance sheet items and the selected macroeconomic variables), we needed to determine the lag-length of the first-differenced variables. Bahmani-Oskooee and Bohl (2000) have shown that the results of this first step are usually sensitive to the lag-length. To verify this, we imposed the optimal lag length of 12 on the first difference of each variable to compute the F-statistics for the joint significance of lagged levels of variables for Equations (2.1) and (2.2). However, only selected computed F-statistics for lag-lengths for all models are reported as in Table 1.

As reported in Table 1, the test outcome of the significance levels for the ARDL models varies with the choice of lag-length. For the entire sample 
period, the computed F-statistics are significant at least at 0.90 level when the order of lags ranges from 1 to 9 for the deposit and at 0.99 level when the order of lags ranges from 1 to 3 for loan. This suggests that there are cointegrating relationship among the selected variables with bank loans and deposits in the whole sample period, implying that there is a tendency for the variables to move together towards a long-run equilibrium.

However, a breakdown of the whole sample period to pre-crisis period and post-crisis period shows somewhat puzzling results. For the pre-crisis period, the computed F-statistics is found to be significant when the order of lags $=1$ and 3 at the $90 \%$ level for deposits but not for loans. Similarly, in the post-crisis period, only the computed F-statistic for deposit is found to be significant at 0.05 probability level at lag-length 3 and 5, but not for loan. This suggests that in the pre- and post-crisis periods, there are cointegrating relationships among the selected variables and deposit, thus the deposit tend to move together towards a long-run equilibrium with other selected variables, but not loans. These results are considered preliminary and indicate that in estimating equations (1.1) and (1.2) we must retain the lagged level of variables.

Table 1: F-statistics for Testing the Existence of a Long-run Equation

\begin{tabular}{lllllll}
\hline \multirow{2}{*}{$\begin{array}{l}\text { Lag- } \\
\text { Length }\end{array}$} & $\begin{array}{l}\text { Entire Sample } \\
(1989: 1 \text { to 2006:12) }\end{array}$ & \multicolumn{2}{l}{$\begin{array}{l}\text { Pre-Crisis Period } \\
(1989: 1 \text { to } \\
\text { 1996:12) }\end{array}$} & $\begin{array}{l}\text { Post-Crisis Period } \\
(1999: 1\end{array}$ \\
\cline { 2 - 7 } & Deposit & Loan & Deposit & Loan & Deposit & Loan \\
\hline 1 & $6.2445^{* * *}$ & $11.4565^{* * *}$ & $4.2705^{* *}$ & 3.2333 & 2.2765 & 2.3551 \\
3 & $4.8321^{* *}$ & $7.8294^{* * *}$ & $3.5698^{*}$ & 1.0575 & $4.2278^{* * *}$ & 1.2158 \\
5 & $5.0051^{* *}$ & $6.0578^{* * *}$ & 1.6817 & 1.9647 & $4.3039^{* *}$ & 1.8131 \\
7 & $4.4483^{*}$ & 3.6087 & 2.3935 & 3.0527 & 3.3626 & 1.4383 \\
9 & $5.3777^{* *}$ & 2.9743 & 3.4045 & 2.4663 & 2.9822 & 2.3469 \\
11 & 4.0312 & 2.432 & 3.001 & 2.1263 & 2.324 & 1.6912 \\
\hline
\end{tabular}

Note: the relevant critical value bounds for the pre- and post-crisis periods are given in Table C1.iii (with unrestricted intercept and no trend; the number of regressors $=4$ ). They are $3.74-5.06$ at the $99 \%$ significance level; $2.86-4.01$ at the $95 \%$ significance level; and $2.45-3.52$ at the $99 \%$ significance level (see Table C1.iii, Pesaran et al., 2001). Meanwhile, the relevant critical value bounds for the entire sample period are given in Table C1.v (with unrestricted intercept and unrestricted trend; the number of regressors = 4). They are $4.40-5.72$ at the $99 \%$ significance level; $3.47-4.57$ at the $95 \%$ significance level; and 3.03 - 4.06 at the 99\% significance level (see Table C1.v, Pesaran et al., 2001). $*$, **, and *** denotes that F-Statistics falls above the $90 \%, 95 \%$ and $99 \%$ upper bound, respectively. 
The findings from this section suggests that there seems to be a long run cointegration among the bank deposit (BD), overnight interest rate (ONR), industrial production index (IPI), inflation (CPI), and real effective exchange rates (RER) during all periods of the study. However, the bank loan are only found to be cointegrated with other selected variables during the entire period of the study, while no cointegration is found during the pre- and post-crisis periods. For further analysis, the study only focuses on the cointegrated variables.

The next step involves estimating equations (2.1) and (2.2) using the appropriate lag-length and model selection criterion based on the Akaike Information Criterion (AIC). Note that the loan variable is only included in the entire sample period but not in the pre-and post-crisis sample periods based on the earlier findings that there is no long run cointegration relationship between loan and the rest of the variables in the pre- and post crisis periods. As suggested in Table 1, the appropriate lag length for the estimated equations is 1 for precrisis and entire sample periods and 5 for post-crisis period. The study simply selects the order of lags for the estimated models based on the higher value of the computed F-statistics.

Table 2: The Long-run ARDL Model Estimates

\begin{tabular}{|c|c|c|c|c|}
\hline & \multicolumn{2}{|c|}{$\begin{array}{c}\text { Entire Sample } \\
(1989: 1 \text { to } 2006: 12)\end{array}$} & \multirow{2}{*}{$\begin{array}{c}\text { Pre-Crisis } \\
\text { Period } \\
(1989: 1 \text { to } \\
\text { 1996:12) } \\
\text { Deposit } \\
{[\mathbf{1 , 1 , 0 , 0 , 0 ]}}\end{array}$} & \multirow{2}{*}{$\begin{array}{c}\text { Post-Crisis } \\
\text { Period } \\
(1999: 1 \text { to } \\
\text { 2006:12) } \\
\text { Deposit } \\
{[\mathbf{1 , 2 , 0 , 1 , 0 ]}}\end{array}$} \\
\hline & $\begin{array}{c}\text { Deposit } \\
{[1,1,0,0,0]}\end{array}$ & $\begin{array}{c}\text { Loan } \\
{[1,0,0,1,0]}\end{array}$ & & \\
\hline$C$ & $\begin{array}{l}-4.4052 \\
(-0.6233)\end{array}$ & $\begin{array}{l}14.1914 \\
(0.4186)\end{array}$ & $\begin{array}{l}-11.1661 \\
(-0.9931)\end{array}$ & $\begin{array}{c}2.8885 \\
(0.9479)\end{array}$ \\
\hline ONR & $\begin{array}{l}0.0788 * * \\
(2.4103)\end{array}$ & $\begin{array}{c}0.0442 \\
(0.8610)\end{array}$ & $\begin{array}{l}-0.0729 \\
(-0.7338)\end{array}$ & $\begin{array}{c}0.0978 \\
(1.4564)\end{array}$ \\
\hline $\ln I P I$ & $\begin{array}{l}1.9806^{*} \\
(1.8358)\end{array}$ & $\begin{array}{l}7.9258 \\
(1.0274)\end{array}$ & $\begin{array}{l}-1.7030 \\
(-0.5643)\end{array}$ & $\begin{array}{c}-.10683 \\
(-0.5144)\end{array}$ \\
\hline $\ln I N F$ & $\begin{array}{c}0.1594 \\
(0.0606)\end{array}$ & $\begin{array}{c}-10.6086 \\
(-.6009)\end{array}$ & $\begin{array}{l}8.4568 \\
(1.1535)\end{array}$ & $\begin{array}{c}3.7116 * * * \\
(4.9072)\end{array}$ \\
\hline $\ln R E R$ & $\begin{array}{c}1.3481 \\
(1.4034)\end{array}$ & $\begin{array}{l}2.0268 \\
(0.7363)\end{array}$ & $\begin{array}{l}-1.2292 \\
(-0.4168)\end{array}$ & $\begin{array}{c}-1.4554 * * * \\
(-3.4990)\end{array}$ \\
\hline & $\begin{array}{c}\text { Adj- } R^{2}=0.998 \\
D-W=1.977\end{array}$ & $\begin{array}{c}\text { Adj- } R^{2}=0.996 \\
D-W=1.993\end{array}$ & $\begin{array}{l}\text { Adj- } R^{2}=0.995 \\
D-W=1.7534\end{array}$ & $\begin{array}{c}\text { Adj- } R^{2}=0.997 \\
D-W=2.066\end{array}$ \\
\hline
\end{tabular}

Note: *, ** and *** denotes significantly at $10 \%, 5 \%$ and $1 \%$ level of significance, respectively. Figures in the parentheses and squared parentheses are the $t$-statistics values and the selected ARDL model. D-W denotes Durbin-Watson test for autocorrelation. Dummy variable is included in the entire sample period; $\mathrm{D}=0$ for the non-crisis period (pre- and post-crisis periods), while $\mathrm{D}=1$ is incorporated during the crisis period. 
The results for the long run estimates based on the ARDL model are provided in Table 2. For the entire sample period, the results provide evidence that deposits are significantly affected by ONR and IPI. In the context of this study, we highlight the significant and positive effect of monetary policy variable, the overnight interest rate, on deposits in the long run. However, none of the variables including the monetary policy variable is significant in affecting loans in entire sample period. In the context of monetary transmission mechanism, this result implies that monetary policy shock is transmitted through bank deposits (the money view) and not through bank loan (the credit view).

Test results from a breakdown of the entire sample period into the preand post-crisis periods show that monetary policy variable is not significant in affecting deposits in both the periods. In particular, none of the selected variables are significant in affecting deposits in the pre-crisis period. In contrast, in the post-crisis period, inflation and real exchange rate are significant in affecting deposit in the long run.

\section{B. Results based on the Impulse Response Functions}

The impulse response functions (IRF) allow for the analysis of the impacts of interest rate shocks on the bank balance sheet items of both banking groups. The IRF shows the magnitude and timing of the responses of the objective variables (the bank balance sheet items) to a shock in the interest rate variable. This enables a comparison of the extent of responses of the bank balance sheet items to the policy shocks. In all cases, impulse response functions are reported for 36 months. To provide some idea of uncertainty surrounding the estimated response, based on Sim and Zha (1995), one standard deviation of confidence bands have been obtained by Monte Carlo integration methods with 1000 replications.

Figure 1 provides the impulse response functions of the responses of the macroeconomic variables to shocks in bank deposit and bank loan for the entire sample period (1989:1 to 2006:12). In terms of the relevance of the bank balance sheet items to monetary policy shocks, the short run analysis indicates that bank deposit responds positively and significantly to changes in the policy interest rate. The impact started to be significant in the fifth month and remained significant until about the $25^{\text {th }}$ month. In contrast, bank loan does not respond significantly to changes in the overnight rates. However, the monetary policy indicator seems to respond positively and significantly to changes in bank loan, implying that the monetary authority reacts to changes in bank loan. Bank loan, therefore, can be termed as the "trigger variable" for monetary policy.

With respect to the responses of the macroeconomic variables to changes in bank deposit and bank loan, data for the whole sample period indicates that the only significant response is that of real output (denoted by IPI) to changes in bank loan, where output increases following a positive innovations in bank loan. This finding implies that bank loan is important in influencing monetary policy direction and economic output in the short run. 
To gain some insights of the changes in the relationship among the variables in the period before and after the Asian financial crisis in 1997/1998, the whole sample period is being divided into the pre-crisis and post-crisis periods. Figure 2 shows the IRF results for the pre-crisis period. As shown in the figure, there seems to be a puzzling result when bank deposit responds negatively significant to changes in the policy interest rate. There is also a significant negative response of ONR to changes in bank deposit, implying in the pre-crisis period, monetary policy has primarily been used in respond to changes in deposit. Bank deposit, however, is insignificant in affecting other macroeconomic variables in the short run in the pre-crisis period. Turning to bank loan, clearly, bank loan is insignificant in the implementation of monetary policy in the pre-crisis period as reflected by the insignificant responses of either bank loan to ONR and ONR to bank loan. However, changes in bank loan are shown to have significant impacts on IPI (IPI responds positively and significantly to changes in BL), CPI (CPI responds positively and significantly to changes in BL) and RER (RER responds negatively and significantly to changes in BL).

Figure 3 provides the IRF results for the post-crisis period. During this period, bank loan seems to play a lesser role in the transmission process of monetary policy, with the exception of bank deposit which seems to respond positively significant to changes in ONR in the first three- to four-month period. Despite this, bank deposit seems to be significant in influencing CPI as the IRF shows that the CPI respons significantly positive to changes in bank deposit. There are still evidences that bank loan is significant in influencing output and a clear indication that bank loan is significant in influencing real exchange rate as shown by the positive and significant IRF.
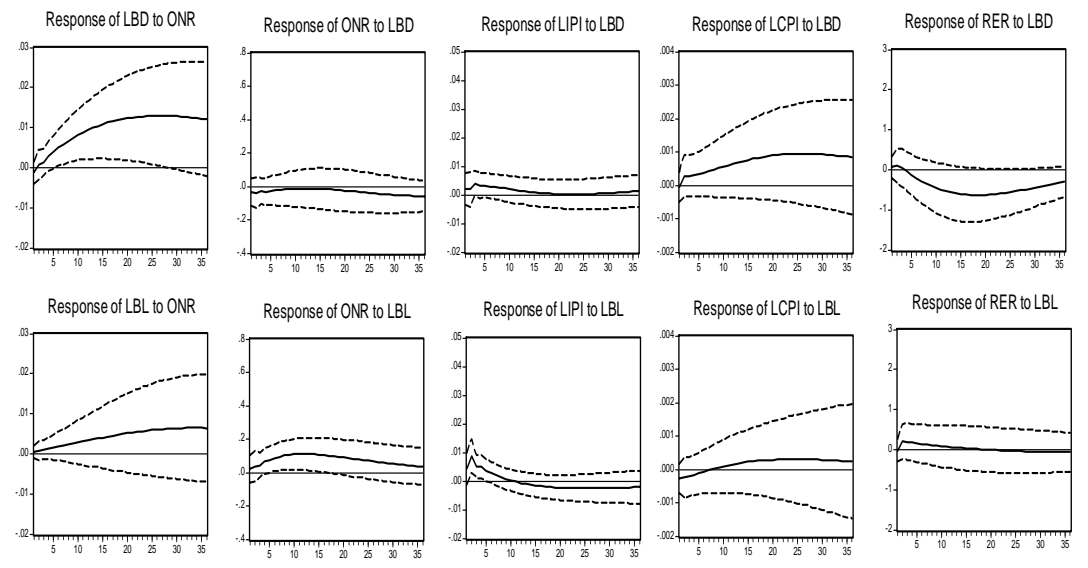

Figure 1: Generalized Impulse-Response Functions, Entire Sample-1989:1 to 2006:12 

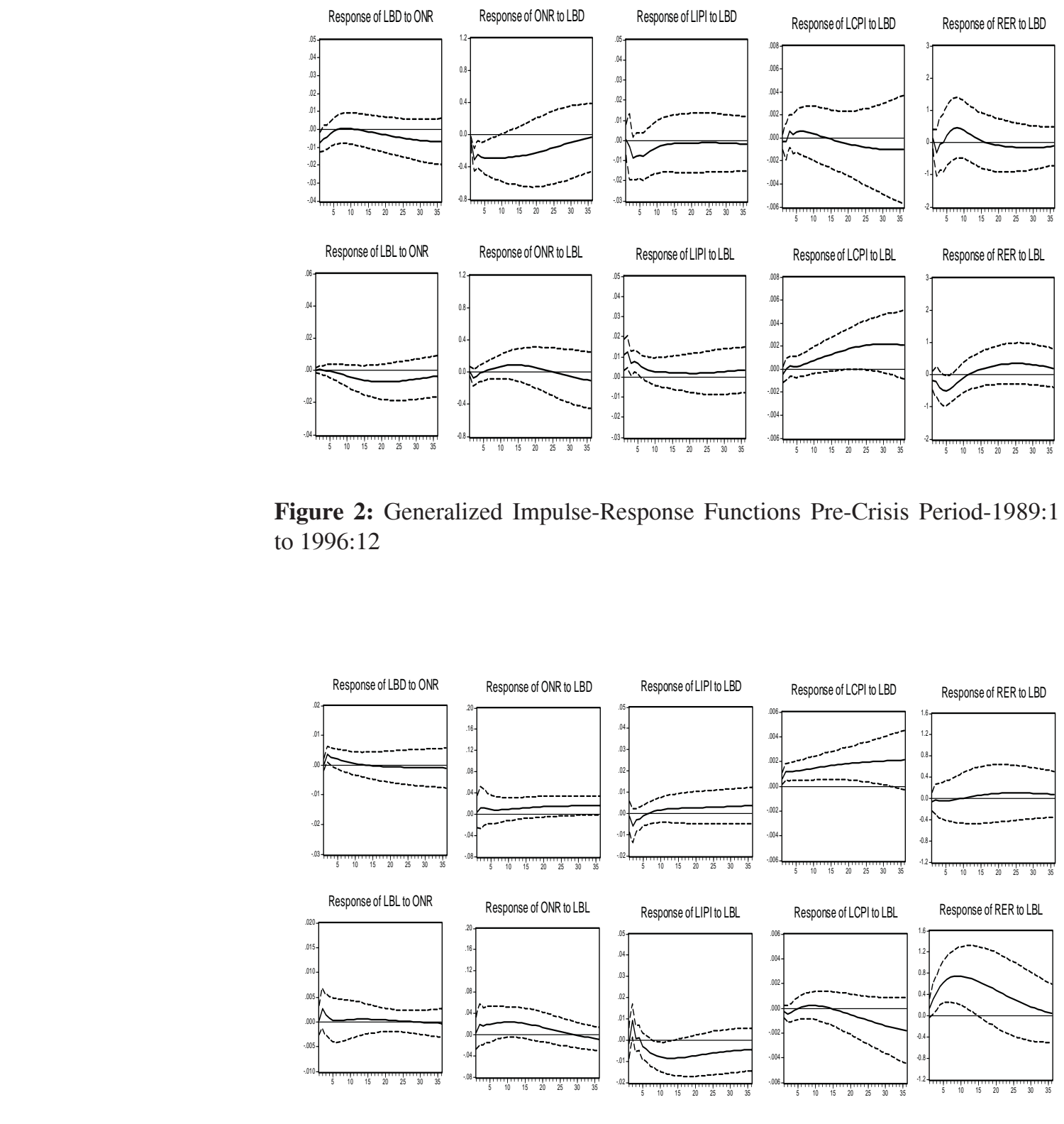

Figure 2: Generalized Impulse-Response Functions Pre-Crisis Period-1989:1 to $1996: 12$



Figure 3: Generalized Impulse-Response Functions Post-Crisis Period-1999:1 to $2006: 12$ 


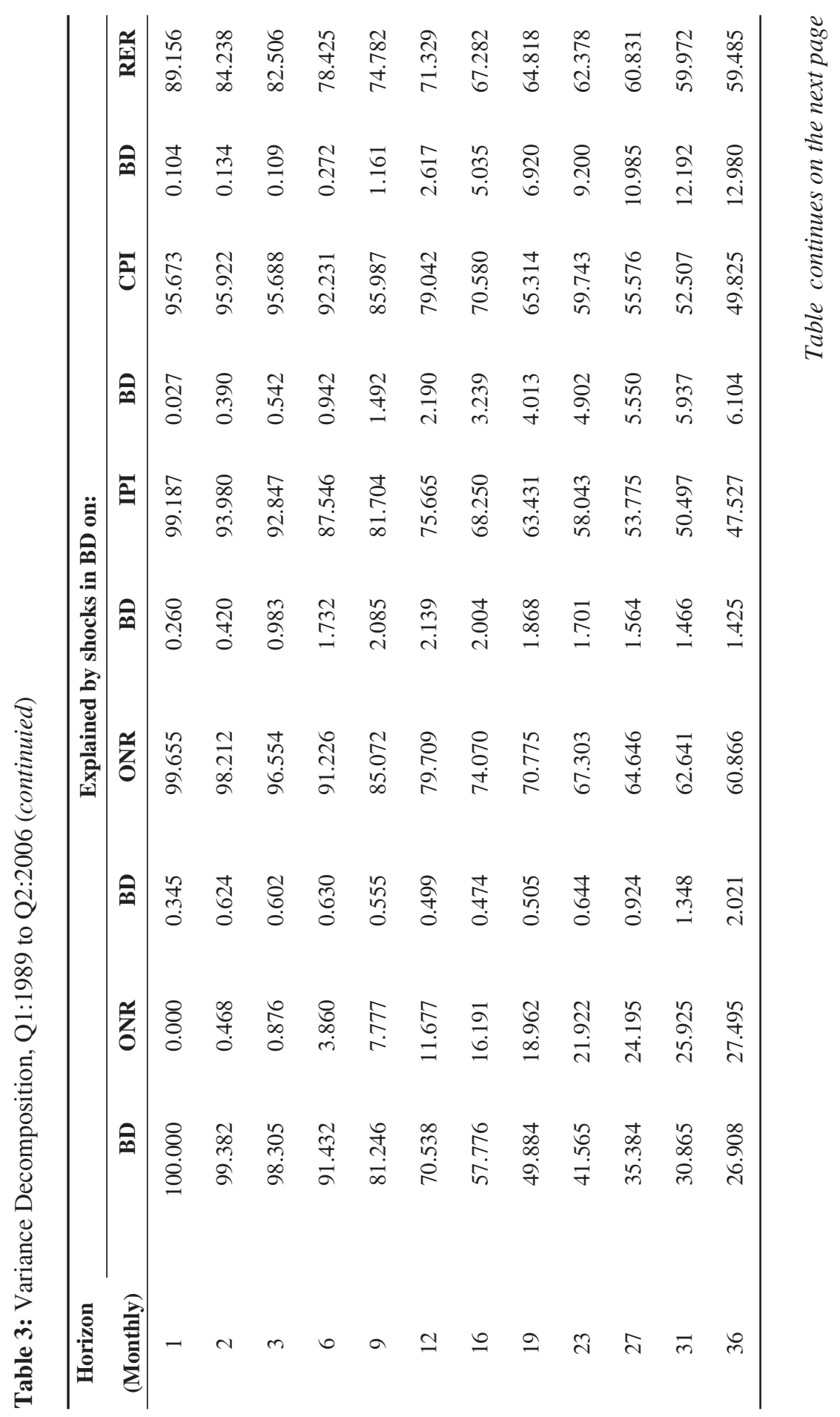




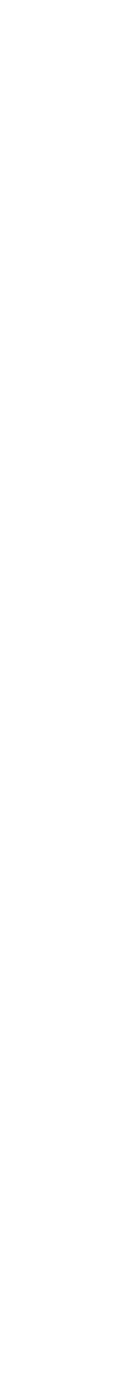

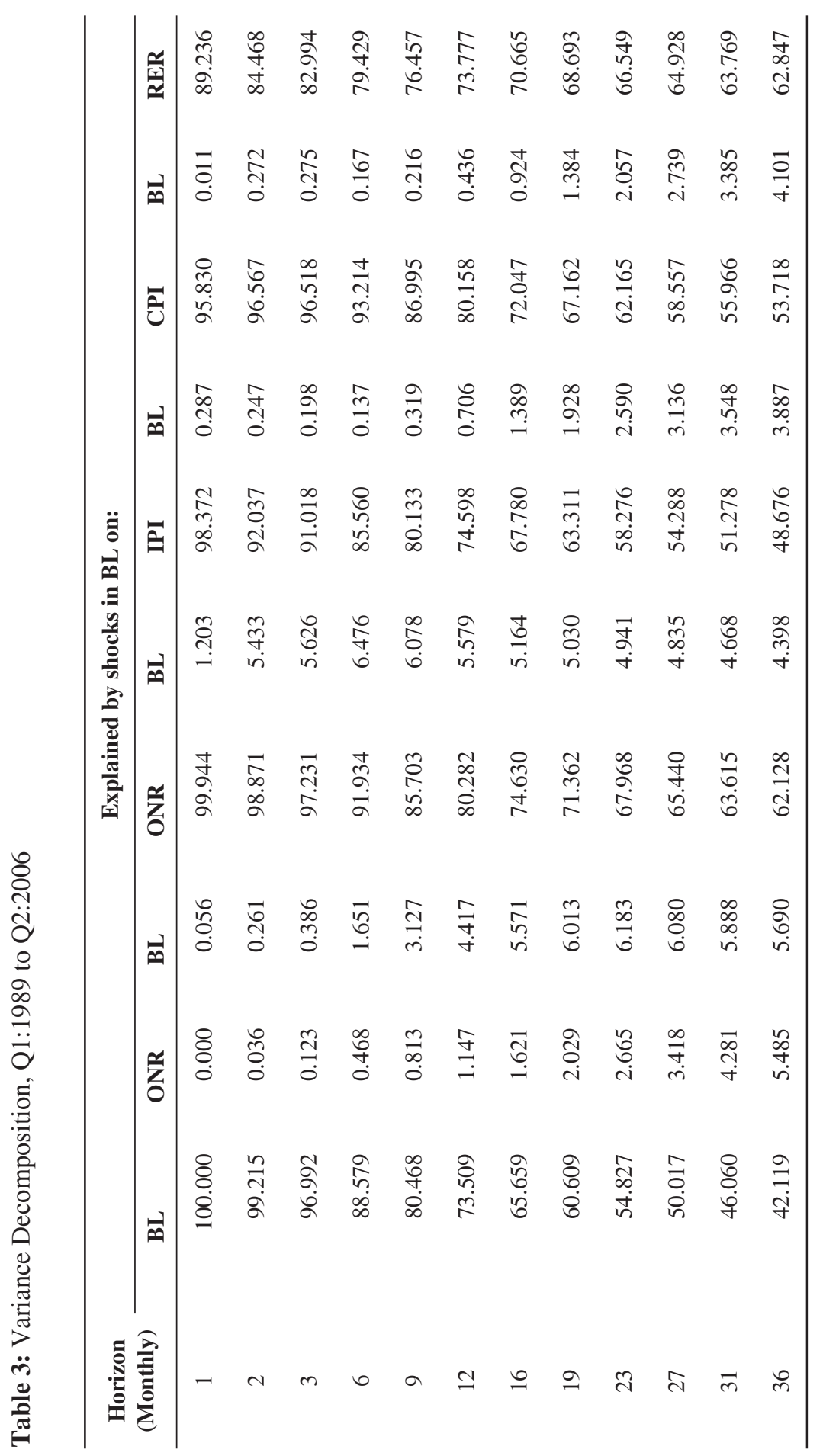



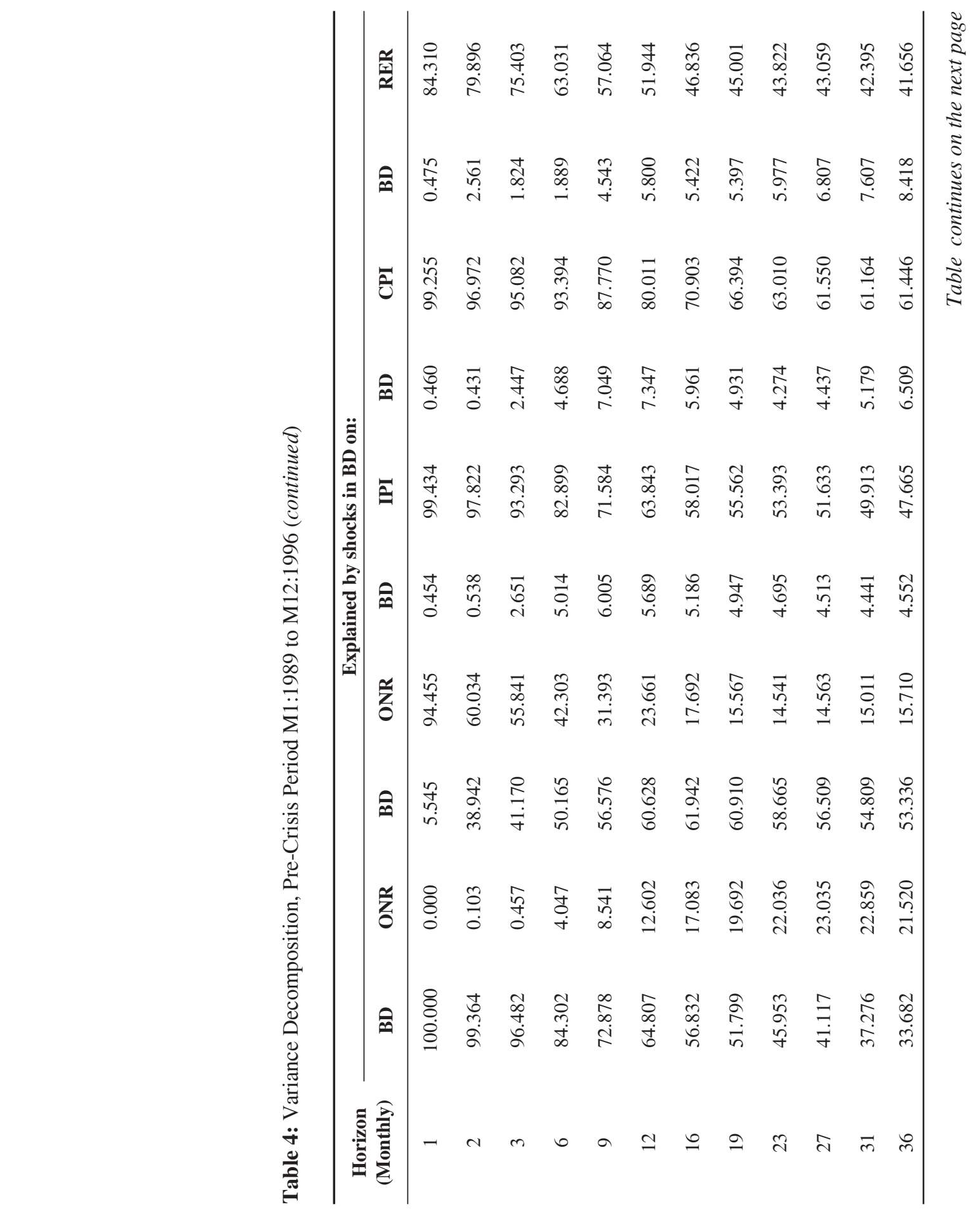

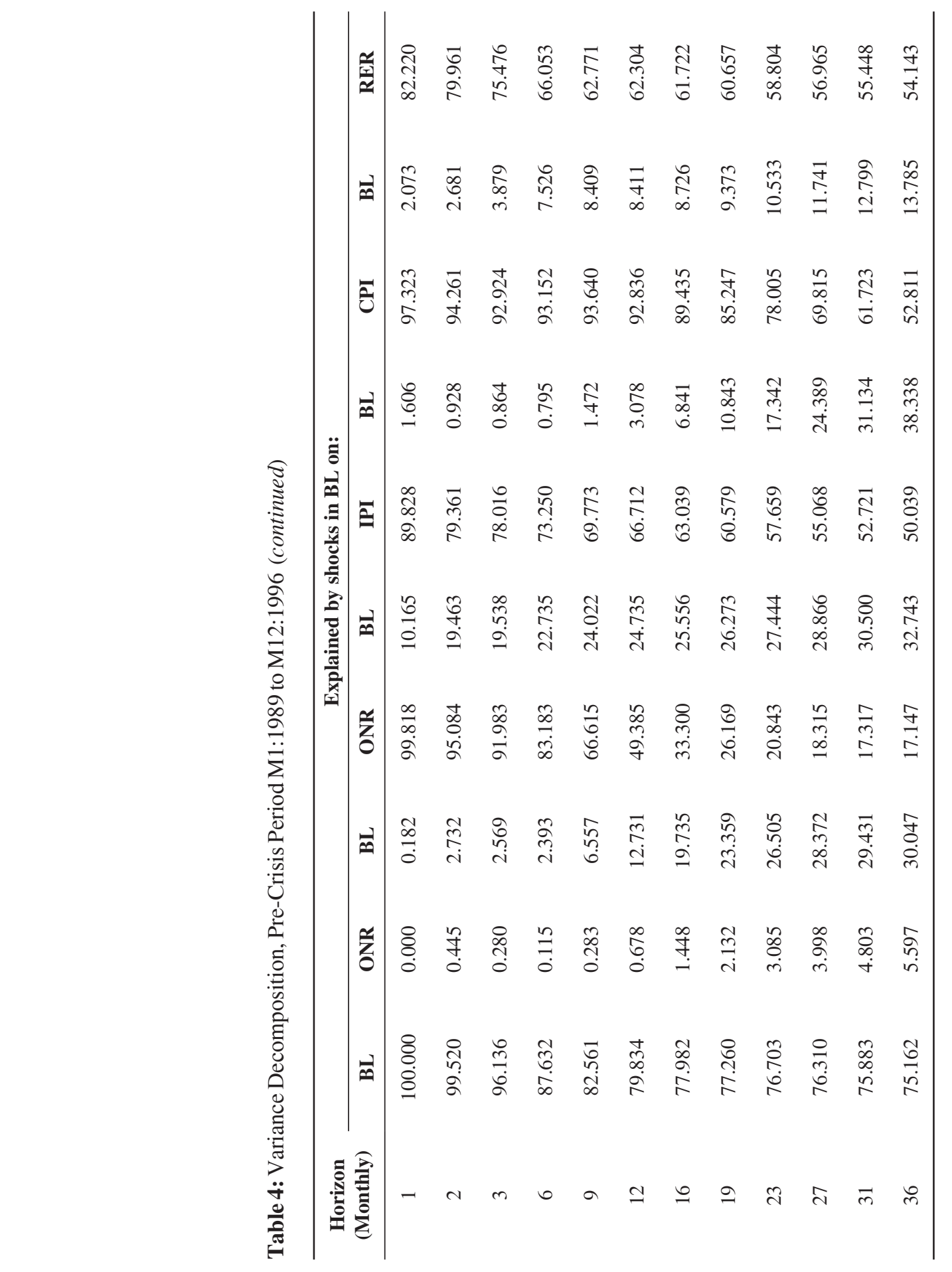


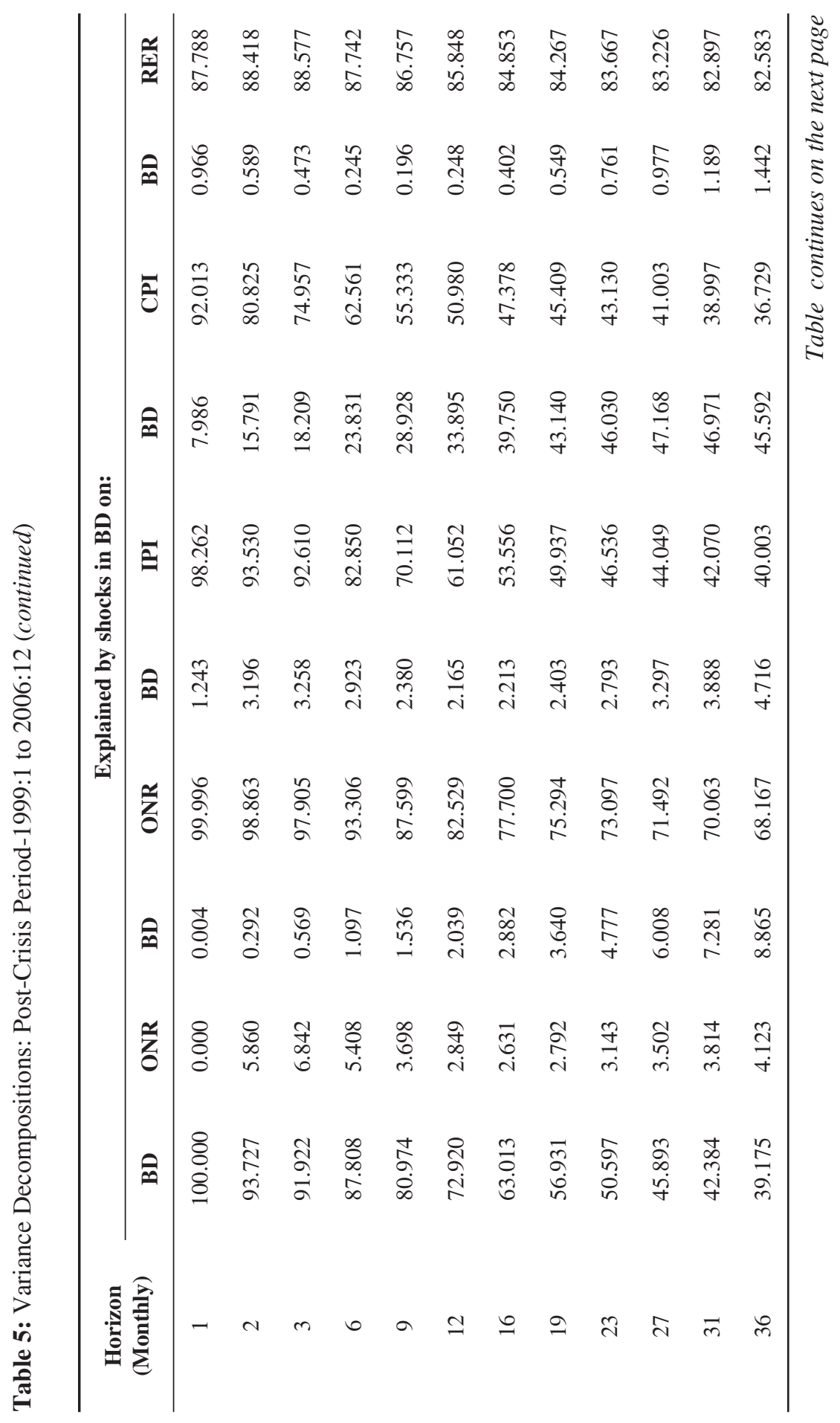






\section{c. Results based on the Variance Decomposition Analysis}

The variance decomposition analysis is used to asses the dynamic interactions between the monetary policy indicator and the bank balance sheet items. At the same time, we provide the variance decomposition of the macroeconomic variables to show the contribution of bank deposits and loans in explaining the variations in the macroeconomic variables. The results from the variance decomposition analysis (VDA) are shown in tables 3, 4 and 5. In general, these results further substantiate our earlier findings based on the IRFs.

Table 3 provides the VDA results for the entire sample period. The results show that the innovations in ONR are highly significant in accounting for the variations in bank deposit. In particular, innovations in ONR account for around 27 percent of the forecast error variance of deposit at the 36-month horizon. In contrast, ONR only accounts for about 6 percent of the forecast error variance of bank loan at the 36-month horizon. Bank deposit therefore, is a significant variable in transmitting monetary policy effects to the economy. Bank loan, however, is shown as a rather important variable to trigger appropriate monetary policy action. Innovations in bank loan account for around 6 percent of the forecast error variance of ONR compared to bank deposit which contribute only around 2 percent of the forecast error variance of ONR.

The role of bank deposit in explaining the forecast error variance of the objective variables is only significant in real exchange rate, where around 13 percent of the forecast error variances in RER are explained by the variations in bank deposit. The contribution of bank loan in explaining the forecast error variances of the objective variables are rather insignificant, ranging from 3 to 6 percent.

Statistics on the tables 4 and 5 are referred to now. For the pre-crisis period, the VDA shows that innovations in ONR are significant in accounting for the forecast error variance of bank deposit, contributing to a maximum of 23 percent at the 27-month horizon. Innovations in ONR, however, are small in accounting for the forecast error variances of bank loan, at around 6 percent maximum. Innovations in bank deposit and loan are significant in accounting for the forecast error variances of ONR, accounting for around 60 percent and 30 percent, respectively. As for the objective variables, bank loan seem to be significant in accounting for the variances in IPI ( 33 percent of the forecast error variances), CPI (38 percent of the forecast error variances) and RER (around 14 percent of the forecast error variances).

There are clear changes in the relationship in the relationship of the variables in the post-crisis period compared to the pre-crisis period. In particular, innovations in ONR account for smaller contribution in accounting for the forecast error variances in both bank deposit (around 7 percent maximum) and bank loan (around 3 percent maximum). Innovations in bank loan remains high in explaining the forecast error variances of ONR at around 16 percent maximum, while that of bank deposit decline to around 9 percent. In this period, there is an obvious contribution of the innovations in bank deposit in accounting for the 
forecast error variances of CPI (around 47 percent maximum), and significant contribution of the innovations in bank loan in accounting for the forecast error variances in RER (around 56 percent maximum) and IPI (around 26 percent maximum).

\section{Conclusion}

In conclusion, the study shows that both bank loans and deposits play crucial role in the monetary transmission process in the economy. Based on the empirical evidence, there is a clear link between the bank loans and deposits and the real economic activity. The credit is a relevant and important channel for monetary transmission in the economy. In view of the important role played by bank lending in the economy, this study re-emphasises the importance of ensuring the stability of banking system. Not only that a healthy and stable banking system ensures an effective implementation of monetary policy, it is indeed a pre-condition towards the overall economic stability. In view of the heavy dependency of the economy on bank lending and the critical role that it plays towards economic stability, it is also good to diversify this dependence away from banks to financial markets.

Author statement: The paper was submitted by Salina Hj. Majid, Assistant Professor in the Department of Economics, International Islamic University, Kuala Lumpur, Malaysia. E-mail: ksalina@iiu.edu.my. The co-author is Sabri Abdul Majid, Assistant Professor in the same university.

\section{References}

Altunbas, Y., Fazylov, O., and Molyneux, P. (2002). Evidence on the bank lending channel in Europe. Journal of Banking and Finance, 26(11), 2093-2110.

Azali, Mohamed (2003). Transmission mechanism in a developing economy: Does money or credit matter? (2nd ed.). University Putra Malaysia Press.

Bahmani-Oskooee, M., and Bohl, M.T. (2000). German monetary unification and the stability of the German M3 money demand function. Economics Letters, 66, 203-208.

Bahmani-Oskooee, M., and Wing Ng, R.C. (2002). Long-run demand for money in Hong Kong: An application of the ARDL model. International Journal of Business and Economics, 1(2), 147-155.

Bank Negara Malaysia. Monthly Statistical Bulletin (Various issues).

Bank Negara Malaysia. (1994). Money and Banking in Malaysia: 35th anniversary edition 1959-1994 (4th ed.).

Bank Negara Malaysia. (1999). The central bank and the financial system in Malaysia: A decade of change (1st ed.).

Bernanke, B. S. (1983). Non-monetary effects of the financial crisis in the propagation of the Great Depression. American Economic Review, 73, 257-276. 
Bernanke, B.S., and Alan S. B. (1988). Credit, money and aggregate demand. AEA Papers and Proceedings, 78(2), 435-39.

Bernanke, B.S. (1992). The federal funds rate and the channels of monetary transmission. American Economic Review, 82(4), 901-921.

Brissimis, S. N., Kamberouglou, N. C., and Simigiannis, G. T. (2001). Is there a bank lending channel of monetary policy in Greece? Evidence from bank level data. European Central Bank. Working Paper (Series No. 104).

Brunner, K., and Allan, H. M. (1972). Money, debt, and economic activity. Journal of Political Economy, 80(5), 951-77.

Brunner, K. (1988). Money and credit in the monetary transmission process: Is it money or credit, or both, or neither? AEA Papers and Proceedings, $78(2), 446-450$.

Brunner, K. (1990). Money supply. Chapter 9. In Elsevier's handbook of monetary economics.

Christiano, L., and Massimo, R. (2001). Money growth monitoring and the Taylor rule. National Bureau of Economic Research. Working Papers (No. 8539).

Dale, S., and Andrew, G. H. (1995). Interest rates and the channels of monetary transmission: Some sectoral estimates. European Economic Review, 39, 1611-1626.

Dotsey, M., and Christopher, O. (1994, Winter). M2 and monetary policy: A critical review of the recent debate. Federal Reserve Bank of Richmond. Economic Quarterly, 41-49.

Driscoll, J. C. (2004). Does bank lending affect output? Evidence from the U.S. states. Journal of Monetary Economics, 51(3), 451-471.

Ehrmann, M., et al. (2001). Financial systems and the role of banks in monetary policy transmission in the Euro area. European Central Bank. Working Paper (Series No. 105).

Farinha, L., and Marques, C. R. (2001). The bank lending channel of monetary policy: Identification and estimation using Portugese micro bank data. European Central Bank. Working Paper (Series No. 102).

Feldstein, M., and James, H. S. (1993). The use of monetary aggregates to target nominal GDP. National Bureau of Economic Research. Working Papers (No. 4304).

Garretsen, H., and Swank, J. (1997). The bank lending channel in the Netherlands: The impact of monetary policy on households and firms. De Nerlandesche Bank. Working Papers (No. 567).

Garretsen, H. (1998). The transmission of interest rate changes and the role of bank balance sheets: A VAR analysis for the Netherlands. Journal of Macroeconomics. 20(2), 325-339.

Gertler, M., and Gilchrist, S. (1993). The role of credit market imperfections in the monetary transmission mechanism: Arguments and evidence. Scandinavian Journal of Economics, 95(1), 43-65.

Gertler, M., and Gilchrist. (1994). Monetary policy, business cycles and the behavior of small manufacturing firms. Quarterly Journal of Economics, 109(2), 309-340. 




Hallsten, K. (1999). Bank loan and the transmission mechanism of monetary policy. Sveriges Riksbank. Working Paper (Series No. 73).

Hess, G.D., and Richard, D.P. (1993). Comparing interest-rate spread and money growth as the predictors of output growth: Granger causality in the sense Granger intended. Journal of Economics and Business, 45(3-4), 247-268.

Hubbard, G. R. (1994). Is there a credit channel for monetary policy? National Bureau of Economic Research. Working Papers (No. 4977).

Ibrahim, M. H. (2001). Financial factors and the empirical behaviour of money demand: A case study of Malaysia. International Economic Journal, 15(3), 55-72.

Ibrahim, M. (2002, November). Money, credit, asset prices and monetary transmission mechanism: Evidence from Malaysia. Paper presented at the 8th Convention of the East Asian Economic Association, Kuala Lumpur.

Ibrahim, M. (2005). Sectoral effects of monetary policy: Evidence from Malaysia. Asian Economic Journal, 19(1), 83-102.

Jansen, D., and Chang, J. C. (2005). The effect of monetary policy on bank lending and aggregate output: Asymmetries from non-linearities in the lending channel. Annals of Economics and Finance, 6, 129-153.

Kakes, Jan. (1998). Monetary transmission and bank lending in the Netherlands. SOM Research Institute, University of Gronigen. Research Report (No. 98C30).

Kassim, S. (2006). Bank lending and monetary policy in Malaysia (Doctoral Dissertation, International Islamic University Malaysia).

Kashyap, A., and S., J. C. (1994). The impact of monetary policy on bank balance sheets. National Bureau of Economic Research. Working Papers (No. 4821).

Kashyap, A., and Stein, J. C. (1995). Monetary policy and bank lending. National Bureau of Economic Research. Working Papers (No. 4317).

Kashyap, A., and Stein, J. C. (1997a). What do a million banks have to say about the transmission of monetary policy. National Bureau of Economic Research. Working Papers (No. 6056).

Kashyap, A., and Stein, J. C. (1997b). The role of banks in monetary policy: A survey with implications for the European Monetary Union. Federal Reserve Bank of Chicago, Economic Perspectives, 2-18.

Kuppers, M. (2002). Curtailing the black box: German banking groups in the transmission of monetary policy. European Economic Review, 45, 19071930.

Laurenceson, J., and Chai, J. C. H. (2003). Financial reform and economic development in China. Cheltenham, UK: Edward Elgar.

Mateut, S., Spiros, B., and Paul, M. (2003). Trade credit, bank lending and monetary policy transmission. Royal Economic Society Annual Conference, (No. 149).

McCallum, B. T. (1990). Could a monetary base rule have prevented the Great Depression? Journal of Monetary Economics, 26(1), 3-26. 
McCallum, B. T. (1999). Recent developments in monetary policy analysis: The roles of theory and evidence. Journal of Economic Methodology, 6(2), 171-198.

McCallum, B. T. (2001). Should monetary policy respond strongly to output gaps? American Economic Review, 91(2), 258-262.

McCallum, B. T. (2004). Monetary policy in economies with little or no money. Pacific Economic Review, 9(2), 81-92.

McCallum, B. T., and Edward, N. (2005). Targeting vs. instrument rules for monetary policy. National Bureau of Economic Research. Working Papers (No. 10612).

Meltzer, A. (1969). Money, intermediation and growth. Journal of Economic Literature, 7(1), 27-56.

Meltzer, A. (1970). Is there an optimal money supply? A discussion. Journal of Finance, 25(2), 450-53.

Meltzer, A. (2001, July). Money and monetary policy: An essay in honor of Darryl Francis. Review, 23-32.

Nelson, E. (2003a). The future of monetary aggregates in monetary policy analysis. Journal of Monetary Economics, 50(5), 1029-1059.

Nelson, E. (2003b). Money and the transmission mechanism in the optimizing IS-LM specification. Center for Economic Policy Research. Discussion Papers (No. 3898).

Pesaran, M.H., Shin, Y., and Smith, R. J. (1996). Testing for the existence of a long-run relationship. DAE Working Paper (No. 9622). Department of Applied Economics, University of Cambridge.

Pesaran, M.H. (2001). Bounds testing approaches to the analysis of level relationships. Journal of Applied Econometrics, 6, 289-326.

Pesaran, M.H., and Pesaran, B. (1997). Working with Microfit 4.0: Interactive econometrics analysis. Oxford University Press.

Scholnick, B. (1996). Asymmetric adjustment of commercial bank interest rates: Evidence from Malaysia and Singapore. Journal of International Money and Finance, 15(3), 485-496.

Suzuki, T. (2001). Is the lending channel of monetary policy important in Australia? The Australian National University. Working Papers in Economics and Econometrics (No. 400).

Tan, E.C. (1997). Money demand amid financial sector developments in Malaysia. Applied Economics, 29(9), 1201-1215.

Tang, T. C. (2000). Commercial bank lending and economic growth in Malaysia: An empirical studies. Borneo Review, 11(1), 60-71.

Tang, T. C. (2002). Banks lending and economic growth in Malaysia: Revisited. Jurnal Analisis, 10(1), 69-87.

Vaithilingam, S., Guru, B. K., and Shanmugam, B. (2003). Bank Lending and Economic Growth in Malaysia. Journal of Asia-Pacific Business, 5(1). 




